\title{
Hormonal Control of Immunoreactive Somatomedin Production by Cultured Human Fibroblasts
}

\author{
David R. Clemmons, Louis E. Underwood, and Judson J. Van WyK, \\ Departments of Pediatrics and Medicine, University of North Carolina, \\ Chapel Hill, North Carolina 27514
}

A BSTRACT Human growth hormone (hGH) is known to be a potent stimulator of somatomedin secretion in vivo. The induction of somatomedin by growth hormone has been difficult to study in vitro, however, because no organ containing a high concentration of somatomedin has been identified. Because fetal mouse explants have been shown to produce somatomedin in vitro, we have undertaken studies to determine whether postnatal human fibroblast monolayers also produce somatomedin, and if so, whether its production is regulated by other hormones. Quiescent human fibroblasts were exposed to serumfree minimum essential medium, and the medium was assayed for somatomedin concentration using a specific radioimmunoassay for somatomedin-C. A progressive rise in immunoreactive somatomedin to $0.08 \mathrm{U} / \mathrm{ml}$ per $10^{5}$ cells per $24 \mathrm{~h}$ was observed over $72 \mathrm{~h}$ of incubation. This was an underestimation of the actual concentration of immunoreactive somatomedin since the amount measured following acid treatment was at least fourfold higher than in the untreated medium. Growth hormone stimulated immunoreactive somatomedin production in a dose-dependent manner: $5 \mathrm{ng} \mathrm{hGH} / \mathrm{ml}=0.1 \mathrm{U} / \mathrm{ml}$ per $10^{5}$ cells; $50 \mathrm{ng} \mathrm{hGH} / \mathrm{ml}$ $=0.25 \mathrm{U} / \mathrm{ml}$ per $10^{5}$ cells. Platelet-derived growth factor and fibroblast growth factor were also stimulatory, but epidermal growth factor, thyroxine, or cortisol had no effect. Media that had been exposed to human fibroblasts stimulated DNA synthesis in BALB/c 3T3 fibroblasts (a cell type that does not produce somatomedin). Medium-derived immunoreactive somatomedin eluted from Sephacryl S-200 in two major peaks $(150,000$ and $8,000 \mathrm{~mol} \mathrm{wt})$. The higher molecular weight peak is similar to the

Dr. Clemmons is a recipient of National Research Service Award AM05991. Dr. Van Wyk is a recipient of a U. S. Public Health Service Research Career award, 4K06A AM14115.

Address reprint requests to Dr. Clemmons.

Received for publication 11 February 1980 and in revised form 8 August 1980. one observed when whole serum was used. These studies provide a model system for studying the humoral and nonhumoral factors that control the biosynthesis of somatomedin by human tissues. Since immunoreactive somatomedin production may be a rate-limiting factor for fibroblast growth, the delineation of the hormonal control of somatomedin production should lead to a better understanding of the mechanisms controlling human fibroblast growth.

\section{INTRODUCTION}

The somatomedins, a family of growth hormonedependent, insulinlike peptide growth factors, have been shown to be mitogenic for a variety of types of cultured cells (1-6). Cartilage from various species and fibroblasts derived from chick (7) and mouse (8) embryos fail to synthesize DNA or undergo mitosis normally when incubated in somatomedin-deficient serum. Evidence has been published, however, that hypopituitary serum is as effective as normal serum in increasing thymidine incorporation (7) and mitosis (9) by cultured human fibroblasts. Although such variables as species of cell origin (7), culture conditions (10), or differences in the methods by which the serum is prepared (11) might account partially for these differences in somatomedin dependancy, other explanations must be considered. For example, the effect of reducing the somatomedin concentration may be masked by a synergism between the small amounts of residual somatomedin remaining in hypopituitary serum and peptides that are not growth-hormone dependent, such as platelet-derived growth factor (PDGF) ${ }^{1}$ (12). Alternatively, it is possible that the effect of somatomedin deficiency in serum is masked by the

\footnotetext{
${ }^{1}$ Abbreviations used in this paper: BSA, bovine serum albumin; DME, Dulbecco's modified minimum essential medium; FCS, fetal calf serum; hGH, human growth hormone; MEM, minimum essential medium; PDGF, platelet-derived growth factor; PPP, platelet-poor plasma; RIA, radioimmunoassay.
} 
somatomedin production of the cultured cells themselves. Indeed, there are reports of production and release of growth factors into medium of cultured transformed cells (13-15) and cells that proliferate in very low serum concentrations (16). Explants of fetal mouse and rat liver $(17,18)$ and a number of other fetal mouse tissues are able to secrete immunoreactive somatomedin into the culture medium. Atkison et al. (19) have reported recently that monolayer cultures of human embryonic lung fibroblasts likewise release immunoreactive somatomedin. Because immunoreactive somatomedin production might be a rate-limiting step for human fibroblast replication, we have assessed the capacity of cultured postnatal human fibroblasts to produce immunoreactive somatomedin. We have also observed the effects of human growth hormone and other mitogens contained in serum on immunoreactive somatomedin production.

\section{METHODS}

Human fibroblasts were purchased from the Human Mutant Genetic Cell Repository, Camden, N. J. Dermal fibroblasts (strain 498) from a normal 3-yr-old donor were used in these studies. BALB/c 3T3 fibroblasts were a gift of Dr. Charles Stiles. Dulbecco's modified minimum essential medium (DME) was purchased from Flow Laboratories, Inc., Rockville, Md. Eagle's minimum essential medium (MEM), fetal calf serum, penicillin, and streptomycin were purchased from GIBCO, Grand Island Biological Co., Grand Island, N. Y. All cultures were plated in plastic petri dishes (Falcon Labware, Div. Becton, Dickinson \& Co., Oxnard, Calif.). Bovine serum albumin (Sigma Chemical Co., St. Louis, Mo., fraction V) was determined to be free of immunoreactive somatomedin-C when assayed at a concentration of $50 \mathrm{mg} / \mathrm{ml}$. [methyl ${ }^{3} \mathrm{H}$ ] Thymidine $(6 \mathrm{Ci} / \mathrm{mM})$ was purchased from New England Nuclear, Boston, Mass. Porcine insulin (PJ 5682) was a gift from Eli Lilly Company, Indianapolis, Ind. Immunochemical grade human growth hormone (hGH) (HS 1144) and bovine growth hormone (B-16) were obtained from the National Pituitary Agency, Baltimore, Md. The human hormone preparation has $0.97 \mathrm{U} \mathrm{hGH} / \mathrm{mg},<1 \%$ contamination by other proteins, and is free of fibroblast growth-factorlike biological activity (8). The somatomedin- $C$ used in these studies was purified to homogeneity as determined by multiple criteria (20). Mouse epidermal growth factor and bovine fibroblast growth factor were purchased from Collaborative Research Inc., Waltham, Mass., and the manufacturer stated that they were $>99 \%$ pure. PDGF was prepared by the following method: outdated human platelets were washed in $17 \mathrm{mM}$ Tris $\mathrm{HCl}, \mathrm{pH} 7.5$, and concentrated by centrifugation. The platelet pellet was freeze-thawed then boiled for $10 \mathrm{~min}$. The boiled extract was centrifuged at $3,000 \mathrm{~g}$ for $30 \mathrm{~min}$ to remove particulate debris. The supernatant fluid was further purified using CM Sephadex chromatography, Pharmacia Fine Chemicals, Piscataway, N. J. (21). PDGF prepared in this manner is purified 250fold over crude platelet homogenate and contains no somatomedin-C by radioimmunoassay. Human platelet poor plasma (PPP) was prepared by placing freshly drawn blood in prechilled plastic centrifuge tubes without anticoagulant and immediately centrifuging at $5,000 \mathrm{~g}$. After removing the supernatant fluid and repeating the centrifugation at $10,000 \mathrm{~g}$ for $30 \mathrm{~min}$, the supernate was heated to $56^{\circ} \mathrm{C}$ for $30 \mathrm{~min}$ and centrifuged at $5,000 \mathrm{~g}$ for $20 \mathrm{~min}$. The resulting supernatant fluid was dialyzed against $0.15 \mathrm{M}$ sodium chloride and stored at $-20^{\circ} \mathrm{C}$ until used. PPP prepared by this method is free of PDGF-like biological activity (12). Hypopituitary PPP was obtained from two hypopituitary donors who were markedly deficient in immunoreactive somatomedin-C $(<4 \mathrm{ng} / \mathrm{ml})$, and was prepared in the same way as normal PPP.

Cell culture techniques. Cells were cultured in $10-\mathrm{cm}$ dishes (Falcon 3001) in MEM containing $10 \%$ fetal calf serum (FCS) and were maintained in a humidified incubator containing $5 \% \mathrm{CO}_{2}$. The medium was changed every $3 \mathrm{rd} \mathrm{d}$ and the cells were harvested by trypsinization and replated once weekly (split ratio, 1:4). Both stock and test cultures were tested for mycoplasma contamination (22) and were found uncontaminated. To assess immunoreactive somatomedin production, fibroblasts (between the 8th and 12th passage) were plated in $1.5-\mathrm{cm}$ wells (Falcon 3008) at a density of 5,000 cells $/ \mathrm{cm}^{2}$ in MEM containing $10 \% \mathrm{FCS}$, penicillin $(100 \mathrm{U} / \mathrm{ml})$, and streptomycin $(100 \mu \mathrm{g} / \mathrm{ml})$. This medium was changed every $3 \mathrm{~d}$ until the cells reached confluency. $3 \mathrm{~d}$ after the last medium change, confluent monolayers were washed three times with serum-free MEM and incubated with $0.5 \mathrm{ml}$ serum-free MEM containing $0.1 \%$ bovine serum albumin (BSA). ${ }^{2}$ The media were sampled at the times indicated in the Results section, either by removing of an aliquot and replacing it with an equal volume of MEM$0.1 \% \mathrm{BSA}$, or by removing the entire $0.5-\mathrm{ml}$ incubation volume. Samples were immediately centrifuged at $1,400 \mathrm{~g}$ for $10 \mathrm{~min}$ to remove particulate debris and the supernatant fluids were stored at $-20^{\circ} \mathrm{C}$ until they were assayed for somatomedin content. Growth hormone and other mitogens were tested at various concentrations by adding the hormone (in MEM-0.1\% BSA) to fibroblast monolayers that had been washed free of serum-containing medium. Samples were then processed and collected in the manner described above. At each time point, duplicate monolayers were washed twice, the cells were removed by trypsinization, and a $0.5-\mathrm{ml}$ aliquot was placed in $9.5 \mathrm{ml}$ of $0.15 \mathrm{M} \mathrm{NaCl}$. Each sample was counted three times in a particle data counter (Coulter Electronics, Inc., Hialeah, Fla.) and the mean of six determinations was used as the cell number per monolayer.

Quantitation of immunoreactive somatomedin in culture media. The preparation of somatomedin-C used for iodination had a specific activity of $10,142 \mathrm{U} / \mathrm{mg}$ protein. ${ }^{3}$ It was iodinated with sodium ${ }^{125}$ ( (Amersham-Searle, Chicago, Ill.) by a chloramine $T$ method (23). Specific activities varied from 190-350 $\mu \mathrm{Ci} / \mu \mathrm{g}$. The iodinated hormone was purified by affinity chromatography using the IgG fraction of a rabbit anti-human somatomedin-C antibody coupled to Sephrose 4B (Pharmacia). The radioimmunoassay used rabbit antihuman somatomedin-C antibody in a final dilution of 1:12,000 (24). This assay is highly specific for somatomedin-C and insulinlike growth factor I, which produce identical curves of competition (25). Insulinlike growth factor II, somatomedinA, or multiplication-stimulating activity III-2 have potencies of $2.4,5$, and $1.2 \%$, respectively. The immunoassay reference standard is an aliquot of the somatomedin preparation used for iodination that has been judged by multiple criteria to have a purity not $<90 \%(20)$.

In addition to measurement of immunoreactive soma-

${ }^{2}$ Cells that were incubated in serum-free medium were $91 \%$ viable by trypan-blue exclusion. In addition, the detachment rate during this period was determined by cell counting to be $<5 \%$.

${ }^{3} \mathrm{l} \mathrm{U}$ is defined as the quantity of somatomedin contained in a pool of normal reference serum and is equivalent to $45 \mathrm{ng}$ of the pure peptide. 
tomedin in unextracted fibroblast culture media, media were assayed after treatment with acid. In the acid treatment, $1.0 \mathrm{ml}$ of the medium sample was incubated with $1.0 \mathrm{ml}$ of $2 \mathrm{M}$ acetic acid at $37^{\circ} \mathrm{C}$ for $30 \mathrm{~min}$. The $\mathrm{pH}$ of the incubation mixture was 3.6. The acidified sample was then lyophilized to dryness and reconstituted in $0.03 \mathrm{M}$ phosphate buffer, $\mathrm{pH}$ 7.5. The immunoreactive somatomedin content of both native and acid-treated media is expressed as $\mathrm{U} / \mathrm{ml}$ per $10^{5}$ cells.

Medium samples that had been acidified and neutralized were tested for their ability to compete with ${ }^{125}$ I-somatomedin$\mathrm{C}$ for binding to placental membranes. Medium aliquots of 5-200 $\mu$ l, ${ }^{125}$ I-somatomedin-C $(20,000 \mathrm{cpm}) /$ tube, and $200 \mu \mathrm{g}$ placental membrane protein were incubated in Tris $0.05 \mathrm{M}, \mathrm{pH} \mathrm{7.4}$, for $16 \mathrm{~h}$. After this incubation the membranes were washed, and the bound radioactivity was detemined. The standard for this assay was a partially purified preparation of somatomedin-C which had been calibrated in the radioimmunoassay (RIA) against pure somatomedin-C.

Measurement of bioactive somatomedin in culture media. BALB/c 3T3 fibroblasts, which do not produce immunoreactive somatomedin, were plated at $d-1,000$ cells/microtest well in DME containing $10 \%$ FCS, penicillin $(100 \mathrm{U} / \mathrm{ml})$, and streptomycin $(100 \mu \mathrm{g} / \mathrm{ml})$. Confluent monolayers were washed twice with serum-free DME and exposed for $5 \mathrm{~h}$ to DME containing partially purified PDGF (500 ng/well). This medium was removed and replaced with DME containing 5\% hypopituitary PPP and either pure somatomedin-C (1-7 $\mathrm{ng} / \mathrm{ml})$ or conditioned MEM (10-60\% of final volume). After $48 \mathrm{~h}$ incubation, DNA synthesis was measured by a previously described autoradiographic method (26).

Characterization of immunoreactive somatomedin in media. $20 \mathrm{ml}$ of medium that had been exposed to fibroblast monolayers for $48 \mathrm{~h}$ were dialyzed (Spectopor 3, mol wt cut off 3,500 ) against 1 liter of $0.025 \mathrm{M}$ phosphate buffer, pH 7.4, for $48 \mathrm{~h}$ with four changes of buffer. The retained material was lyophilized to dryness, reconstituted with $1.0 \mathrm{ml}$ water, applied to a $1.6 \times 80-\mathrm{cm}$ Sephacryl S-200 column, and eluted with $0.05 \mathrm{M}$ phosphate buffer, pH 7.4. Each fraction was acidified for $30 \mathrm{~min}$ ( $\mathrm{pH}$ adjusted to 3.6), lyophilized to dryness, reconstituted in $0.03 \mathrm{M}$ phosphate buffer (pH 7.4), and assayed for immunoreactive somatomedin content. An additional $10-\mathrm{ml}$ aliquot of medium was acidified with an equal volume of $2.0 \mathrm{M}$ acetic acid, final $\mathrm{pH} 3.6$, and lyophilized to dryness. The material was reconstituted in $0.5 \mathrm{ml}$ acetic acid containing $10,000 \mathrm{cpm}{ }^{125} \mathrm{I}$-somatomedin-C, applied to a $1.6 \times 20-\mathrm{cm}$ Sephadex G-50 column and eluted with acetic acid. The fractions were lyophilized to dryness

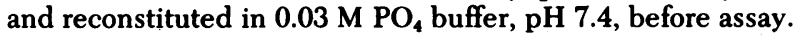

\section{RESULTS}

Measurement of immunoreactive somatomedin in fibroblast medium. Although confluent monolayer cultures of human fibroblasts were demonstrated to produce a peptide that reacted in our RIA, the amount of this material in medium was generally underestimated. When 20-120 $\mu \mathrm{l}$ of medium that had been exposed to cells for $72 \mathrm{~h}$ were incubated with ${ }^{125} \mathrm{I}$ somatomedin-C in immunoassay buffer, the curve of competition obtained was not parallel to that obtained using pure standard (Fig. 1). Because the somatomedins have been shown to circulate in plasma bound to binding proteins, and cultured cells have been demonstrated to produce substances with

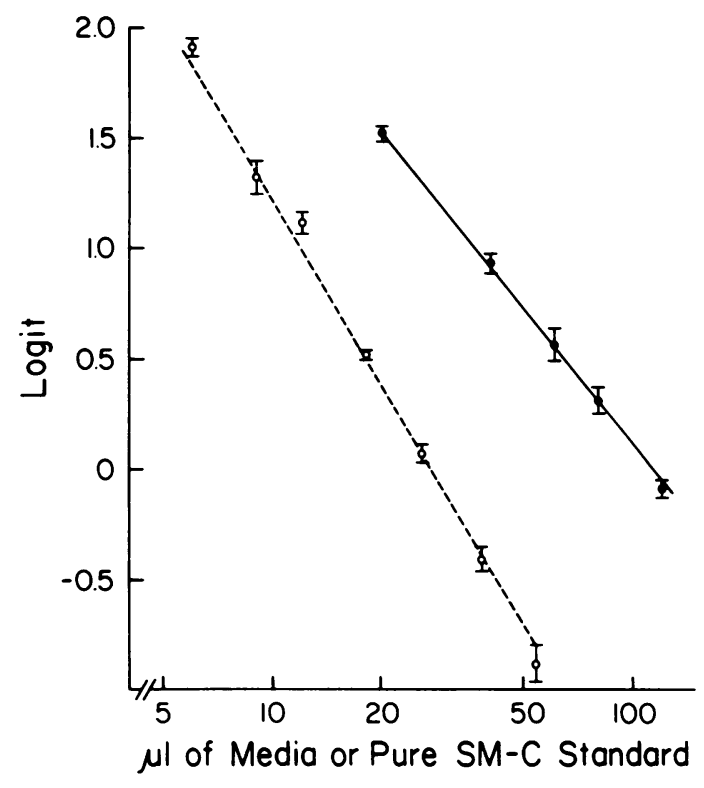

FIGURE 1 Dose-response curve for unextracted, conditioned medium. Medium that had been exposed to human fibroblasts for $24 \mathrm{~h}$ was assayed at multiple concentrations for somatomedin-C (SM-C) content. The results are plotted on a logit-log scale and the dose response of medium $(O)$ is compared to the dose responses of pure somatomedin- $\mathrm{C}(\mathrm{O})$.

somatomedin binding activity, we were concerned that this lack of parallelism was the result of binding proteins in the fibroblast culture media. We also observed that when graded quantities of pure somatomedin- $C$ were added to the medium, the recovery of the added peptide was incomplete $(\sim 23 \%)$. This incomplete recovery was not the result of degradation of somatomedin-C during immunoassay, because incubation of ${ }^{125}$ I-somatomedin-C with medium for $48 \mathrm{~h}$ $\left(4^{\circ}\right.$ or $\left.24^{\circ} \mathrm{C}\right)$ resulted in no loss of binding when samples were subsequently exposed to an excess of somatomedin antibody. Several perturbations of medium were tested to eliminate the effect of these interfering substances, and to achieve parallelism and full recovery. Heating media at $24^{\circ}, 37^{\circ}$, or $56^{\circ} \mathrm{C}$ for variable periods of time had no effect. Reducing the $\mathrm{pH}$ of medium samples to 3.6 for $30 \mathrm{~min}$ and subsequent neutralization, however, produced dose-response curves parallel to the pure standard (Fig. 2). $62 \%$ of pure somatomedin-C that had been added to acidified media samples was recovered, and there was an eightfold enhancement of somatomedin activity over media which had not been acid treated. In subsequent studies, therefore, media were subjected routinely to acid treatment before assay.

Production of immunoreactive somatomedin by fibroblasts. Confluent cultures of human fibroblasts were washed three times with serum-free MEM and exposed to MEM containing $0.1 \%$ BSA. No 


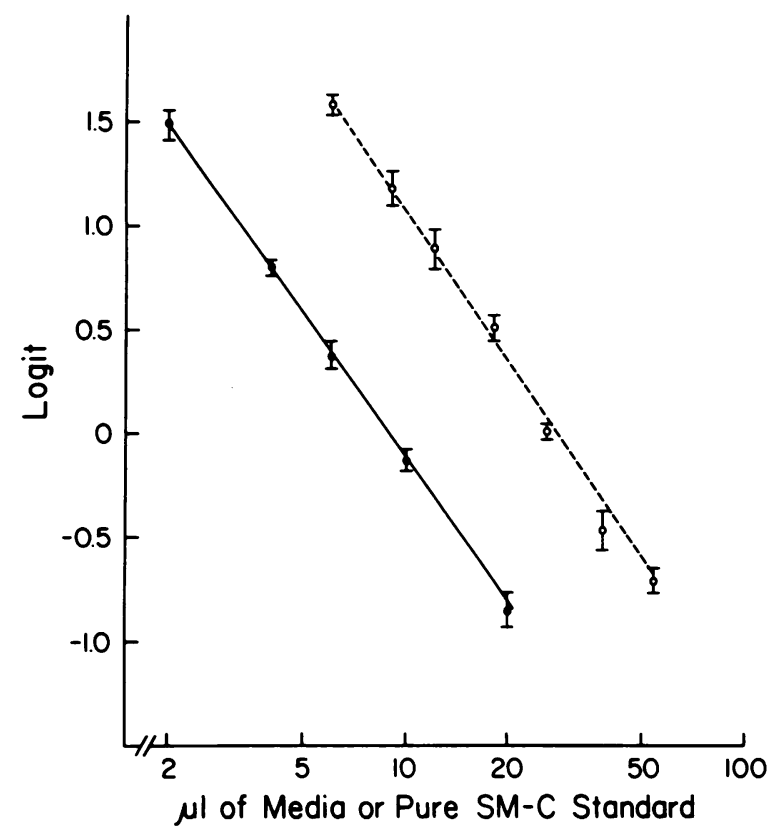

FIGURE 2 Dose-response curve for acid-treated medium. Medium ( $1.0 \mathrm{ml})$ that had been exposed to human fibroblasts for $24 \mathrm{~h}$ was acidified by adding $1.0 \mathrm{ml}$ of $2.0 \mathrm{M}$ acetic acid (final pH 3.6). After $30 \mathrm{~min}$ at $37^{\circ} \mathrm{C}$, the mixture was neutralized using $0.015 \mathrm{ml}$ of $0.1 \mathrm{~N} \mathrm{NaOH}$. The doseresponse curve obtained using acidified medium $(O)$ is compared to that obtained using pure somatomedin-C (O).

immunoreactive somatomedin could be detected in the third wash. Medium samples removed at 24, 48, and $72 \mathrm{~h}$ showed a progressive rise in immunoreactive somatomedin concentration (Fig. 3). The quantity of immunoreactive somatomedin present in the media at $72 \mathrm{~h}$ was two times greater than the concentration present in the MEM-10\% FCS in which the cells originally had been grown and 12 times greater than the immunoreactive somatomedin content of the cellular cytosol at the start of the incubation. ${ }^{4}$

Several additional experiments were performed to exclude the possibility that immunoreactive somatomedin in FCS had been taken up by the cells and then released. When ${ }^{125} \mathrm{I}$-somatomedin-C $(4 \mathrm{ng} / \mathrm{ml}$ of medium) was incubated with fibroblast cultures for $48 \mathrm{~h}$ and the cells were washed 3 times, only $1.3 \%$ of the labeled hormone remained in the cell-associated fraction. In another experiment, the MEM-0.1\% BSA

4Te somatomedin concentration in the cytosol was determined as follows: the cells from 12 monolayers were removed by scraping into prechilled $0.05 \mathrm{M}$ phosphate buffer, $\mathrm{pH} 7.4$, homogenized and centrifuged at $100,000 \mathrm{~g}$ for $60 \mathrm{~min}$. The supernatant fraction was assayed for somatomedin-C concentration. Controls for recovery included addition before homogenization of ${ }^{125}$ I-somatomedin-C $(20,000 \mathrm{cpm})$ and pure unlabeled somatomedin-C (1 ng/ml). Recovery was $>98 \%$ by both methods.

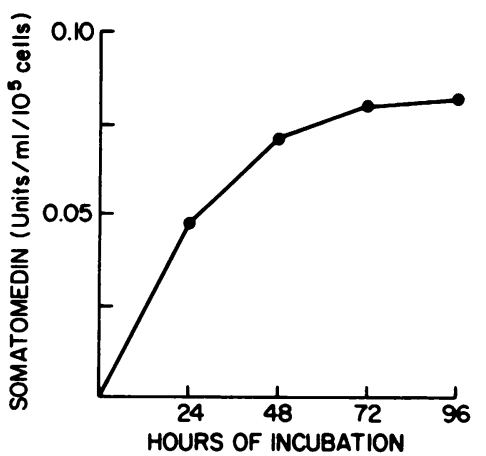

FIgURe 3 Production of somatomedin-C by human fibroblast cultures. Confluent human fibroblast cultures were exposed to serum-free MEM containing $0.1 \%$ BSA. Media were removed at the times indicated, and the somatomedin concentration determined by RIA.

was changed at 12 -h intervals for $72 \mathrm{~h}$. The sum of the individual immunoreactive somatomedin concentrations of the six samples was 3.1 times greater than the immunoreactive somatomedin concentration in MEM-10\% FCS. Additionally, cells incubated in the presence of MEM- $0.1 \%$ BSA containing cyclohexamide (50 $\mu \mathrm{M}$ ) exhibited markedly diminished immunoreactive somatomedin production (Table I). Finally, sixth passage cultures were maintained in MEM containing $10 \%$ hypopituitary serum $(<2 \mathrm{ng} / \mathrm{ml}$ somatomedin-C) for $3 \mathrm{wk}$. The monolayers were then washed extensively and incubated as usual in MEM$0.1 \%$ BSA. After $48 \mathrm{~h}$, the concentration of immunoreactive somatomedin was $0.06 \mathrm{U} / \mathrm{ml}$.

TABLE I

Effect of Cyclohexamide on Somatomedin Production

\begin{tabular}{lccc}
\hline & \multicolumn{3}{c}{ Time of incubation } \\
\cline { 2 - 4 } Test substance & 8 & 24 & 48 \\
\hline Control (no addition) & $\begin{array}{c}\text { Undetect- } \\
\text { able }\end{array}$ & $0.04^{*}$ & 0.07 \\
Cyclohexamide & $\begin{array}{c}\text { Undetect- } \\
\text { able }\end{array}$ & $\begin{array}{c}\text { Undetect- } \\
\text { able }\end{array}$ & $\begin{array}{c}\text { Undetect- } \\
\text { able }\end{array}$ \\
hGH (10 ng/ml) & $\begin{array}{c}0.02 \\
\text { Undetect- } \\
\text { hGH (10 ng/ml) }\end{array}$ & $\begin{array}{c}\text { Undetect- } \\
\text { able }\end{array}$ & $\begin{array}{c}\text { Undetect- } \\
\text { able }\end{array}$ \\
\hline
\end{tabular}

Confluent fibroblast monolayers were washed with serumfree MEM, then exposed to MEM-0.1\% BSA (control) or MEM-0.1\% BSA plus hGH, $10 \mathrm{ng} / \mathrm{ml}$. Additional wells contained either of these media plus cyclohexamide $(50 \mu \mathrm{m})$. At the times indicated, media from quadruplicate plates were removed and stored for somatomedin determination.

* Somatomedin values are expressed as units per milliliter per $10^{5}$ cells. 
Growth hormone stimulation of immunoreactive somatomedin production. When graded amounts of hGH were incubated for $24 \mathrm{~h}$ with confluent fibroblast monolayers containing only MEM-0.1\% BSA, there was a dose-dependent (1-40 $\mathrm{ng} \mathrm{hGH/ml)}$ increase in somatomedin production (Fig. 4). These fibroblasts, therefore, are sensitive to $\mathrm{hGH}$ and display increases in immunoreactive somatomedin production at concentrations of growth hormone within the range normally found in human serum.

Other stimuli of immunoreactive somatomedin production by fibroblasts. In an additional series of experiments, confluent human fibroblasts were exposed to MEM-0.1\% BSA containing either hGH (10 ng/ml), PDGF (500 ng/ml), or PDGF plus growth hormone. With these stimuli, cultured fibroblast media exhibited a progressive increase in immunoreactive somatomedin production over time (Fig. 5). The combination of PDGF and growth hormone was additive at the concentrations tested. A variety of other factors had little effect on immunoreactive somatomedin production (Table II). In addition to PDGF and hGH, stimulatory effects were noted when fibroblast growth factor was added, but not by cortisol, thyroxin, mouse epidermal growth factor, or porcine insulin. Bovine growth hormone, added over a concentration range $5-500 \mathrm{ng} / \mathrm{ml}$, showed significant stimulation only at the $500 \mathrm{ng} / \mathrm{ml}$ concentration. This result indicates that bovine growth hormone is $\sim 1 \%$ as potent as $\mathrm{hGH}$ in inducing the formation of immunoreactive somatomedin in this system.

Biological and physicochemical properties of immunoreactive somatomedin produced by fibroblasts. To determine whether fibroblast-derived somatomedin can stimulate cell division, conditioned medium was added to BALB/c 3T3 cell monolayers in the presence of 5\% hypopituitary PPP ( $<4 \mathrm{ng} / \mathrm{ml}$ immunoreactive somatomedin-C). For comparison, additional monolayer cultures received graded amounts of unlabeled

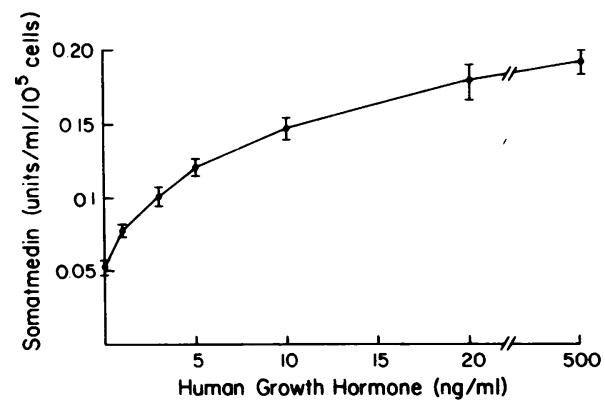

FIGURE 4 Effect of hGH on somatomedin-C production by fibroblasts. Confluent human fibroblast cultures were exposed to increasing concentrations of hGH in MEM-0.1\% BSA for $24 \mathrm{~h}$. The results are expressed as units of somatomedin-C per milliliter per $10^{5}$ cells.

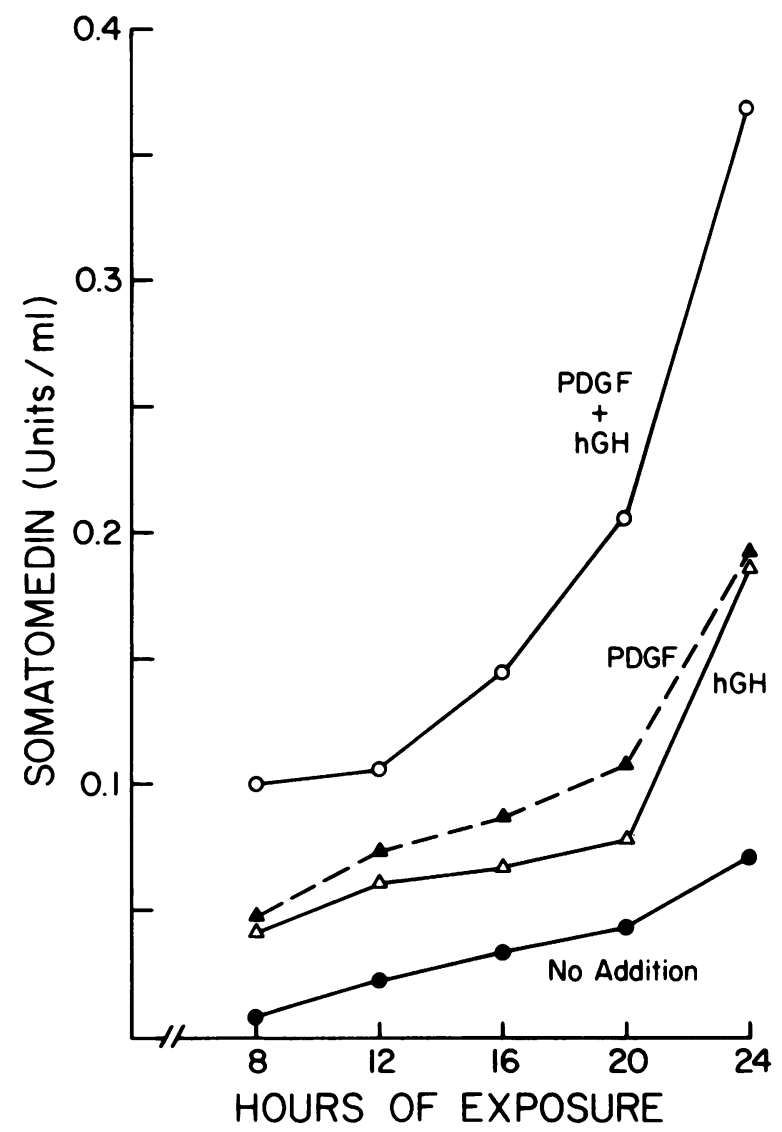

FIGURE 5 Effect of hGH and PDGF on SM-C production. Confluent monolayers were exposed to serum-free MEM containing no addition $(\Theta), 10 \mathrm{ng} / \mathrm{ml}(\Delta) \mathrm{hGH}, 500 \mathrm{ng} / \mathrm{ml}$ PDGF $(\triangle)$, or hGH plus PDGF $(O)$ in $0.1 \%$ BSA. After incubation for $24 \mathrm{~h}$, the media were harvested and somatomedin-C content was determined. Results are expressed as units of somatomedin-C per milliliter per $10^{5}$ cells.

somatomedin-C plus 5\% hypopituitary PPP. The addition of $120 \mu$ l conditioned MEM resulted in stimulation of DNA synthesis that was equal to that produced when hypopituitary PPP plus $7 \mathrm{ng} / \mathrm{ml}$ somatomedin- $C$ was added (Table III). A dose response to conditioned medium was demonstrable over the concentration range tested $(10-60 \% \mathrm{vol} / \mathrm{vol})$.

Conditioned medium that had been acidified and neutralized (see Methods) was tested for its capacity to compete with ${ }^{125}$ I-somatomedin-C for binding to placental membrane receptors. A parallel doseresponse curve was obtained and the somatomedin concentration by the receptor assay was estimated to be 12 vs. $9.2 \mathrm{ng} / \mathrm{ml}$ by RIA.

On Sephacryl S-200 chromatography, the immunoreactive material in the media migrated in three distinct peaks (Fig. 6). Approximately $60 \%$ of the activity eluted in the $140,000 \mathrm{~mol}$ wt region and $\sim 30 \%$ migrated in a region similar to free somatomedin. 
TABLE II

Effect of Hormones on Somatomedin Production

\begin{tabular}{lc}
\hline \multicolumn{1}{c}{ Test substance } & Somatomedin concentratio \\
\hline & U/ml/10 cells \\
Basal & \\
$\quad$ No addition & $0.05 \pm 0.005$ \\
hGH $(10 \mathrm{ng} / \mathrm{ml})$ & $0.17 \pm 0.007^{*}$ \\
Fibroblast growth factor $(10 \mathrm{ng} / \mathrm{ml})$ & $0.13 \pm 0.008 \ddagger$ \\
Platelet factor $(800 \mathrm{ng} / \mathrm{ml})$ & $0.19 \pm 0.008^{*}$ \\
Epidermal growth factor & $0.05 \pm 0.003$ \\
Hydrocortisone $(0.17 \mu \mathrm{M})$ & $0.04 \pm 0.007$ \\
Hydrocortisone $(1.7 \mu \mathrm{M})$ & Undetectable \\
Thyroxine $(0.13 \mu \mathrm{M})$ & $0.05 \pm 0.006$ \\
Porcine insulin $\left(8.0 \times 10^{11} \mathrm{M}\right)$ & $0.06 \pm 0.007$
\end{tabular}

Quiescent human fibroblast cultures grown to confluency in MEM-10\% FCS $(80,000$ cells/well) were washed three times and then exposed to serum-free MEM, containing $0.10 \% \mathrm{BSA}$ plus the test mitogen. After incubation for $24 \mathrm{~h}$ at $37^{\circ} \mathrm{C}, 0.5 \mathrm{ml}$ of medium was removed, centrifuged at $1,400 \mathrm{~g}$ for $20 \mathrm{~min}$, and the supernatant fluids stored at $-20^{\circ} \mathrm{C}$. Before assay the samples were acidified and neutralized (see Methods). The results are expressed as units of somatomedin-C per milliliter per $10^{5}$ cells.

* Significant at $P<0.01$.

‡ Significant at $P<0.05$.

TABLE III

Biologic Activity of Fibroblast Media

\begin{tabular}{lc}
\hline \multicolumn{1}{c}{ Concentrations } & Labeled nuclei \\
\hline & $\%$ \\
Media & 22 \\
No addition & 34 \\
$10 \%$ Conditioned medium & 47 \\
$30 \%$ Conditioned medium & 77 \\
$60 \%$ Conditioned medium & \\
Somatomedin & 36 \\
$1 \mathrm{ng} / \mathrm{ml}$ & 49 \\
$4 \mathrm{ng} / \mathrm{ml}$ & 75 \\
$7 \mathrm{ng} / \mathrm{ml}$ &
\end{tabular}

Microtest wells containing confluent quiescent BALB/c 3T3 cells $(10,000$ cells/well) were exposed to PDGF $(1.0 \mu \mathrm{g} /$ well $)$ in DME for $5 \mathrm{~h}$. These media were then removed, the monolayers were washed twice, and serum-free MEM that had been exposed to human fibroblast cultures for $48 \mathrm{~h}$ was added (in the percentage of the total volume listed) along with DME containing 5\% hypopituitary PPP (total vol $=0.2 \mathrm{ml}$ ). The somatomedin content of the conditioned medium was $0.12 \mathrm{U} / \mathrm{ml}$. This concentration of pure somatomedin- $\mathrm{C}$ has been shown by us and others (39) to stimulate fibroblast replication. After $48 \mathrm{~h}$ of incubation, each well was washed twice with $70 \%$ methanol and DNA synthesis was measured by autoradiography. 200 nuclei were counted in each well and each result (the mean of two wells) is expressed as the percentage of cells labeled. Additional wells received a known quantity of pure somatomedin-C standard instead of serum-free medium and the results were determined as described.
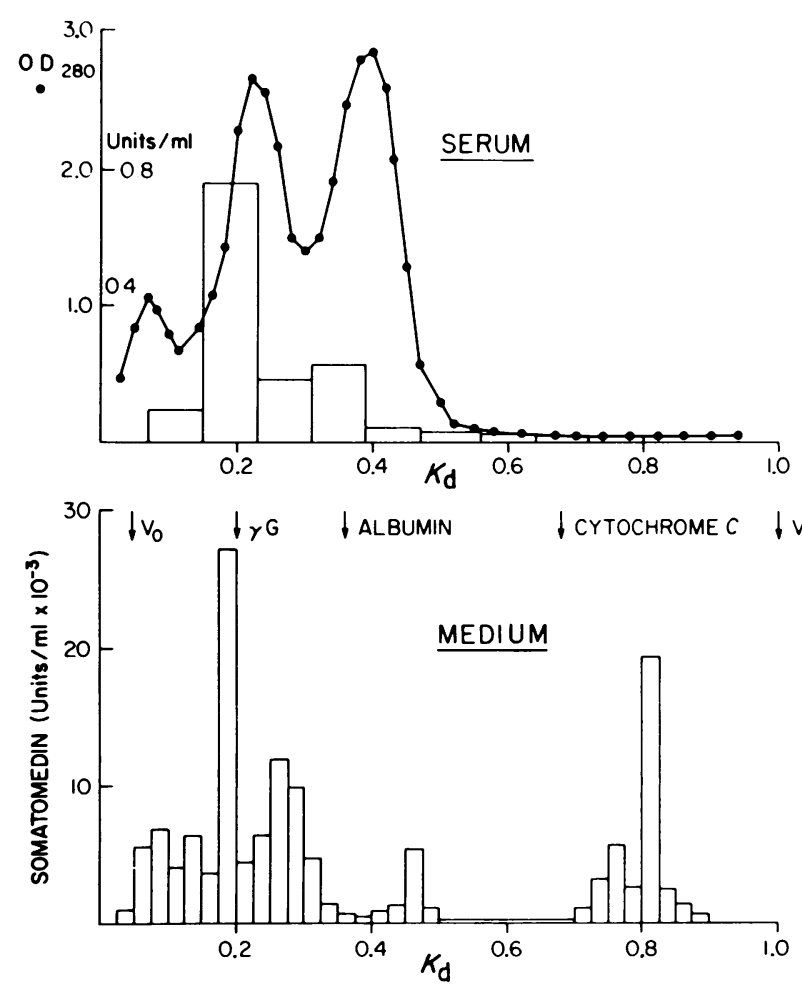

Figure 6 Gel filtration chromatography of medium on Sephacryl S-200. Medium that had been exposed to fibroblast cultures for $24 \mathrm{~h}$ was dialyzed at $4^{\circ} \mathrm{C}$ against $0.005 \mathrm{M}$ phosphate buffer for $48 \mathrm{~h}, \mathrm{pH} \mathrm{7.4}$, applied to a Sephacryl S200

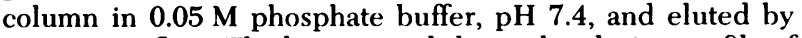
continuous flow. The lower panel shows the elution profile of fibroblast medium somatomedin. The upper shows the elution profile of normal human serum on Sephadex G 200.

A minor peak was detectable in the $90-100,000 \mathrm{~mol}$ wt region. Medium that was acidified and neutralized, then preincubated for $16 \mathrm{~h}$ at $4^{\circ} \mathrm{C}$ with ${ }^{125} \mathrm{I}$-somatomedin-C $(20,000 \mathrm{cpm})$, and chromatographed on Sephacryl S-200 showed no activity in the $140,000 \mathrm{~mol}$ wt region. Approximately $60 \%$ of the activity now eluted in the 70 and $35,000 \mathrm{~mol}$ wt regions and $40 \%$ in the mol wt region corresponding to free somatomedin. The ${ }^{125}$ I-somatomedin-C also migrated in the region corresponding to free somatomedin. Similar chromatographic results were obtained when medium was acidified and chromatographed on G-50 Sephadex at $\mathrm{pH}$ 3.6. Under these conditions, $\sim 71 \%$ of the immunoreactive material appeared in the void volume, and $29 \%$ chromatographed at $K_{\mathrm{av}}=0.5$, the region corresponding to free somatomedin (Fig. 7).

\section{DISCUSSION}

Observations of Burk (27), Shodell (15), and Stoker et al. (28) suggested that certain types of cultured cells have the capacity to secrete growth factors into serum- 


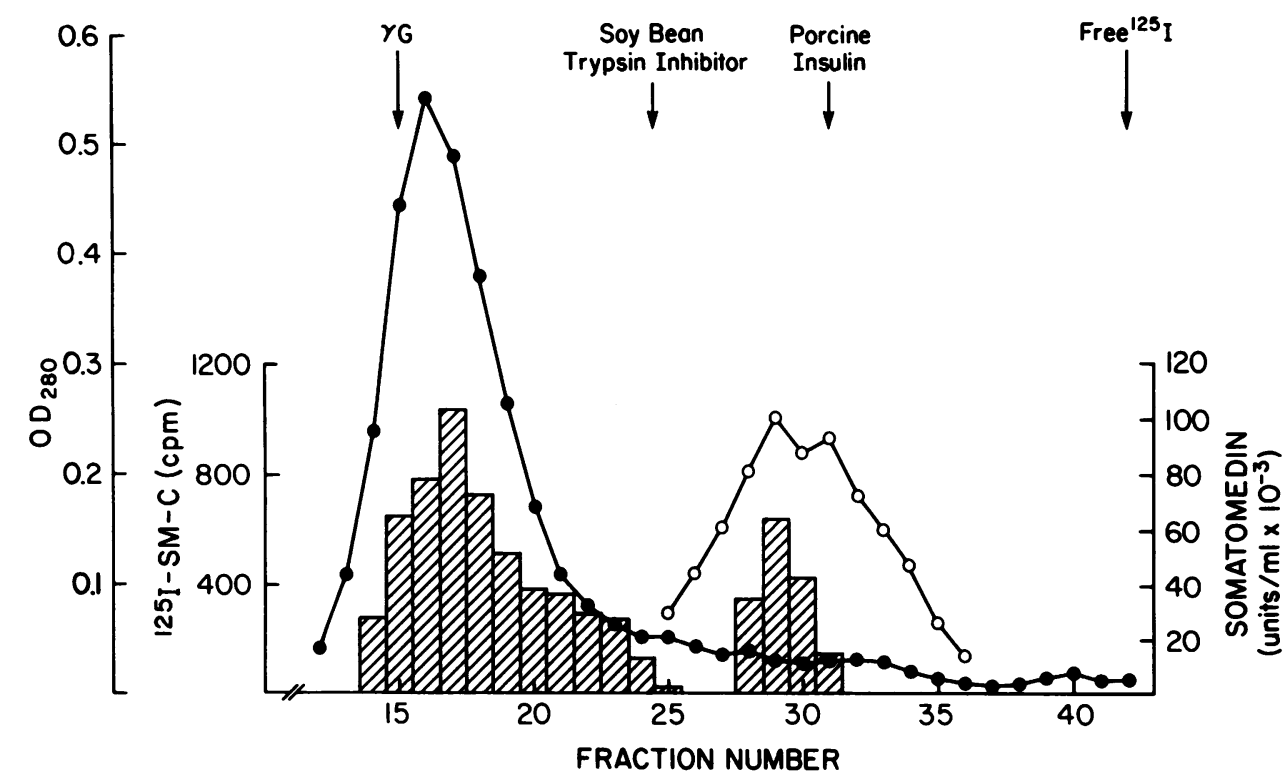

FIGURE 7 Gel filtration chromatography of medium on Sephadex G-50. Medium which had been exposed to fibroblast cultures for $24 \mathrm{~h}$ was acidified ( $\mathrm{pH} 3.6$ ) and incubated for $18 \mathrm{~h}$ at $4^{\circ} \mathrm{C}$ with 125I-somatomedin-C (SM-C). This mixture was applied to a Sephadex G-50 column (20 $\times 1.6 \mathrm{~cm}$ ) and eluted with acetic acid, $\mathrm{pH} 3.6 .9, \mathrm{OD}_{280} ;$, somatomedin (units per milliliter $\left.\times 10^{-3}\right) ; O,{ }^{125} \mathrm{I}-\mathrm{SM}-\mathrm{C}(\mathrm{cpm})$.

free medium. Dulak and Temin (29) extended these observations when they isolated and characterized multiplication-stimulating activity from medium which had been exposed to buffalo rat liver cells. More recent studies by Rechler et al. (18) have identified multiple peptides with mitogenic activity in this conditioned medium. The physicochemical and growth-promoting properties of these peptides are similar to purified somatomedin-C and to multiplication-stimulating activity which had been isolated from calf serum. More recently, Todaro and Delarco (30) have shown that SV-40 transformed cells produce a polypeptide which crossreacts in the multiplicationstimulating activity-radioreceptor assay. Other important growth factors such as colony-stimulating factor (31), macrophage growth factor (32), and nerve growth factor (33) are produced by a variety of cultured cells. Cultured human fibroblasts have also been reported to produce a small peptide which stimulates endothelial cell division (34) and a macromolecule which enhances fibroblast attachment and stimulates replication in the presence of serum (35). The chemical characteristics of these substances and their spectra of biologic activity have not been defined.

It has generally been assumed that growth factors such as somatomedin must be transported through blood to their target tissues to stimulate growth. The demonstration by others that growth factors are produced by cultured cells prompted us to question whether human fibroblasts might produce immuno- reactive somatomedin that in turn might stimulate proliferation within the culture. Our results, as well as those of Wiedman et al. (36), indicate that fibroblasts are capable of producing a factor(s) that crossreacts in immunoassays for basic somatomedin. In humans it is not known if this property is limited to fibroblasts; however, studies using fetal mouse tissue explants suggest that it may be a phenomenon common to more than one cell type. Based on the observations that cartilage is not sensitive to direct stimulation by growth hormone (37), it can be assumed that this tissue and perhaps others require blood-borne somatomedin for growth.

Preliminary studies indicate that a large portion of the immunoreactivity in cultured fibroblast medium is in an acid-stable, high molecular weight form. Similarities between this material and somatomedin-C purified from human plasma are suggested by the findings that the former $(a)$ reacts with specific somatomedin-C antiserum, (b) crossreacts with somatomedin- $C$ in the placental membrane radioreceptor assay, and $(c)$ stimulates DNA synthesis in BALB/c 3T3 cells, which require the addition of somatomedin$\mathrm{C}$ for replication.

Precise measurement of the immunoreactive somatomedin-like material is difficult, probably because of interference by the somatomedin binding proteins contained in the culture medium. Acidifying and then neutralizing media corrected the nonparallelism of media immunoreactivity, eliminated protein-binding 
activity, and significantly enhanced immunoreactivity. Similar findings have been observed with media taken from cultured explants of fetal mouse tissues (17); however, the loss of ${ }^{125}$ I-somatomedin-C is contrary to results reported using human serum (38). Since acid treatment does not result in conversion to a lower molecular weight form, its enhanced apparent immunoreactivity may result from better access of antibody to previously inaccessible somatomedin. Alternatively, some of the apparent immunoreactivity in the macromolecular fraction after acid treatment could result from interference of binding proteins in the RIA. This, however, appears unlikely because we observed parallelism between pure somatomedin- $\mathrm{C}$ and the acidtreated media and there is no ${ }^{125} \mathrm{I}$-somatomedin-C binding on gel chromatography.

The major question concerning growth hormone's mechanism of action has been whether it stimulates cell replication directly, or acts through the induction of an intermediary substance such as somatomedin. Our results seem to strenghten the possibility of an indirect action. They demonstrate that the growth hormone, at concentrations comparable to those in human serum, stimulates cultured postnatal human fibroblasts to produce immunoreactive somatomedin. We have presented evidence recently that supports the hypothesis that somatomedin mediates the growthpromoting effects of growth hormone on cultured cells (39). Specifically, we have observed that when medium containing hypopituitary PPP and growth hormone is removed and replenished every $2 \mathrm{~h}$, replication of fibroblast cultures does not proceed at a normal rate. Frequent changing of medium containing hypopituitary PPP and purified somatomedin-C, however, allows replication to proceed normally. These observations suggest that somatomedin production is necessary for normal fibroblast replication and the effect of growth hormone on fibroblasts is mediated through somatomedin production.

The potential importance of growth hormone-regulated immunoreactive somatomedin production by fibroblasts is that it might be the mechanism whereby growth hormone stimulates generalized cell growth. In contrast, stimulation of fibroblast immunoreactive somatomedin production by PDGF represents a nongrowth hormone-dependent mechanism by which fibroblast replication in culture could be stimulated. PDGF has been proposed as a growth factor which stimulates the rapid proliferation of fibroblasts during wound healing (40). Stimulation of immunoreactive somatomedin production by PDGF could be one mechanism by which these events occur.

The system we have used for assessing immunoreactive somatomedin production has a number of uses. In addition to serving as a tool for the study of the hormonal control of immunoreactive somatomedin biosynthesis, it could be useful in assessing nonhormonal factors that regulate immunoreactive somatomedin production, and as an alternate means for determining the biological potency of growth hormone preparations.

There is evidence that fibroblast growth factor stimulates cellular proliferation by a mechanism similar to PDGF (8). The capacity of a highly purified fibroblast growth factor preparation to substitute in our system for partially purified PDGF suggests that a single peptide in the platelet factor preparation may be responsible for stimulation of immunoreactive somatomedin production. The failure of epidermal growth factor, thyroxin, and insulin to stimulate immunoreactive somatomedin production suggests that the process is specific for certain peptides and implies that epidermal growth factor and insulin stimulate mitosis through mechanisms independent of immunoreactive somatomedin production. Our studies indicate that bovine growth hormone is a weak stimulator of immunoreactive somatomedin production. The concentrations of bovine growth hormone required are comparable to those necessary to compete with $\mathrm{hGH}$ for binding to receptors in human tissue (41).

The observation that hypopituitary serum is as potent as normal serum in stimulating fibroblast replication suggests that immunoreactive somatomedin production by the fibroblast cultures may be nullifying any differences in the intrinsic mitogenic capacity of these two types of sera. The findings of Moses et al. (7), that hypopituitary serum stimulates DNA synthesis by cultured cells, could be explained if their hypopituitary test serum contained enough PDGF to stimulate in vitro production of immunoreactive somatomedin that, in turn, stimulated proliferation of their cultured fibroblasts. Alternatively, other somatomedins that are slightly growth hormonedependent and, therefore present in hypopituitary serum, may stimulate replication in this cell type.

Although immunoreactive somatomedin generally has been considered to be a blood-borne hormone with widespread stimulatory effects on cell proliferation, our findings indicate that fibroblast-derived somatomedin may regulate proliferation of selected cell types at or near its site of production. Such local regulation could provide a mechanism whereby focal cellular proliferation could be coordinated without stimulation of adjacent tissues. Such a mechanism might be an important component of normal physiologic processes such as wound healing, or in disorders of cellular proliferation such as atherosclerosis.

\section{ACKNOWLEDGMENTS}

We gratefully acknowledge Dr. W. J. Pledger's gift of partially purified platelet-derived growth factor and his advice in planning cell culture studies. We wish to thank Ms. Diane 
Chapin and Eyvonne Bruton for their technical assistance and Ms. Cindy Sullivan for her help in preparing this manuscript.

\section{REFERENCES}

1. Morrell, B., and E. R. Froesch. 1973. Fibroblasts as an experimental tool in metabolic and hormone studies. II. Effects of insulin and nonsuppressible insulin-like activity (NSILA-s) on fibroblasts in culture. Eur. J. Clin. Invest. 3: 119-123.

2. Dulak, N. C., and H. M. Temin. 1973. Multiplication stimulating activity for chick embryo fibroblasts from rat liver cell conditioned medium: a family of small peptides. J. Cell. Physiol. 81: 161-170.

3. Nissley, S. P., and M. M. Rechler. 1977. Multiplication stimulating activity (MSA): a somatomedin-like polypeptide from cultured rat liver cells. In Third Decennial Review Conference: Cell Tissue and Organ Cultures. National Cancer Institute monograph 48: 167-178.

4. Van Wyk, J. J., L. E. Underwood, R. L. Hintz, D. R. Clemmons, S. J. Voina, and R. P. Weaver. 1975. Explorations of the insulin like and growth-promoting properties of somatomedin by a membrane receptor assays. Adv. Metab. Disord. 8: 127-150.

5. Hollenberg, M. D., and L. Fryklund. 1977. Insulin and somatomedins A and B: comparison of biologic activities in cultured human skin-derived fibroblasts. Life Sci. 21: $943-950$.

6. Florini, J. R., M. L. Nicholson, and N. C. Dulak. 1977. Effects of peptide anabolic hormones on growth of myoblasts in culture. Endocrinology. 101: 32-41.

7. Moses, A. C., K. L. Cohen, R. Johnsonbaugh, and S. P. Nissley. 1978. Contribution of human somatomedin activity to the serum growth requirement of human skin fibroblasts and chick embryo fibroblasts in culture.J. Clin. Endocrinol. Metab. 46: 937-946.

8. Stiles, C. D., G. T. Capone, C. D. Scher, H. N. Antoniades, J. J. Van Wyk, and W. J. Pledger. 1979. Dual control of cell growth by somatomedins and platelet derived growth factor. Proc. Natl. Acad. Sci. U. S. A. 76: 1279-1283.

9. August, G. R., R. R. Cheng, W. Hung, and J. C. Houck. 1973. Fibroblast proliferative activity in the sera of growth hormone deficient patients. Horm. Metab. Res. 5: 340-341.

10. McKeehan, W. L., D. P. Genereaux, and R. G. Ham. 1978. Assay and partial purification of factors from serum that control multiplication of human diploid fibroblasts. Biochem. Biophys. Res. Commun. 80: 1013-1021.

11. Wall, R. T., L. A. Harker, L. J. Quadracci, and G. E. Striker. 1978. Factors influencing endothelial cell proliferation in vitro. J. Cell. Physiol. 96: 203-214.

12. Pledger, W. J., C. D. Stiles, H. N. Antoniades, and C. D. Scher. 1977. Induction of DNA synthesis in Balb/c 3T3 cells by serum components: a reevaluation of the commitment process. Proc. Natl. Acad. Sci. U. S. A. 74: 44814485.

13. De Larco, J. E., and G. J. Todaro. 1978. A human fibrosarcoma cell line producing multiplication stimulating activity (MSA)-related peptides. Nature (Lond.) 272: 356-358.

14. Bourne, H. R., and E. Rozengurt. 1976. An 18,000 molecular weight polypeptide induces early events and stimulates DNA synthesis in cultured cells. Proc. Natl. Acad. Sci. U. S. A. 73: 4555-4559.

15. Shodell, M. 1972. Environmental stimuli in the progres- sion of BHK/21 cells through the cell cycle. Proc. Natl. Acad. Sci. U. S. A. 69: 1455-1459.

16. Smith, G. L., and H. M. Temin. 1974. Purified multiplication-stimulating activity from rat liver conditioned medium: comparison of biologic activities with calf serum, insulin, and somatomedin. J. Cell. Physiol. 84: $181-192$.

17. D'Ercole, A. J., G. T. Applewhite, and L. E. Underwood. 1980. Evidence that somatomedin is synthesized by multiple tissues in the fetus. Dev. Biol. 75: 315-328.

18. Rechler, M. M., H. J. Eisen, O. Z. Higa, S. P. Nissley, A. C. Moses, E. E. Shilling, I. Fennoy, C. B. Bruni, L. S. Phillips, and K. L. Baird. 1980. Characterization of a somatomedin (insulin-like growth factor) synthesized by fetal rat liver organ cultures. J. Biol. Chem. 254: $7942-7950$.

19. Atkison, P. R., E. R. Weidman, B. Bhaumick, and R. M. Bala. 1980. Release of somatomedin-like activity by cultured WI-38 human fibroblasts. Endocrinology. 106: 2006-2012.

20. Svoboda, M. E., J. J. Van Wyk, D. G. Klapper, R. E. Fellows, F. E. Grissom, and R. J. Schlueter. 1980. Purification of somatomedin-C from human plasma: chemical and biological properties, partial sequence analysis and relationship to other somatomedins. Biochemistry. 19: 790-797.

21. Antoniades, H. N., C. D. Scher, and C. D. Stiles. 1979. Purification of human platelet derived growth factor. Proc. Natl. Acad. Sci. U. S. A. 79: 1809-1813.

22. Chen, T. R. 1977. In situ detection of mycoplasma contamination in cell cultures by fluorescent Hoechst 33258 stain. Exp. Cell Res. 104: 255-262.

23. D'Ercole, A. J., L. E. Underwood, J. J. Van Wyk, C. J. Decedue, and D. B. Foushee. 1976. Specificity, topography and ontogeny of the somatomedin-C receptor in mammalian tissues. In Growth Hormone and Related Peptides. A. Pecile and E. Muller, editors. Excerpta Medica, Amsterdam. 190-201.

24. Furlanetto, R. W., L. E. Underwood, J. J. Van Wyk, and A. J. D'Ercole. 1977. Estimation of somatomedin-C levels in normals and patients with pituitary disease by radioimmunoassay. J. Clin. Invest. 60: 648-657.

25. Van Wyk, J. J., M. E. Svoboda, and L. E. Underwood. 1980. Evidence from radioligand assays that somatomedin$\mathrm{C}$ and insulin-like growth factor I are similar to each other and different from other somatomedins. J. Clin. Endocrinol. Metab. 50: 206-208.

26. Antoniades, H. N., D. Stathakos, and C. D. Scher. 1975. Isolation of a cationic polypeptide from human serum that stimulates proliferation of 3 T 3 cells. Proc. Natl. Acad. Sci. U. S. A. 72: 2635-2639.

27. Burk, R. R. 1973. A factor from a transformed cell line that affects cell migration. Proc. Natl. Acad. Sci. U. S. A. 70: 369-372.

28. Stoker, M. G. P., G. D. Clarke, and M. Thornton. 1972. Density dependent stimulation of thymidine incorporation in BHK 21 cells by active material released from the same cells. J. Cell. Physiol. 78: 345-354.

29. Dulak, N. C., and H. M. Temin. 1973. A partially purified polypeptide fraction from rat liver cell conditioned medium with multiplication-stimulating activity for embryo fibroblasts. J. Cell. Physiol. 81: 153-160.

30. Todaro, G. J., and J. E. Delarco. 1978. Growth factor production by sarcoma virus-transformed cells. Cancer Res. 38: 4147-4154.

31. Stanley, E. R., and P. M. Heard. 1977. Factors reg- 
ulating macrophage production and growth: purification and some properties of colony stimulating factor from medium conditioned by mouse cells. J. Biol. Chem. 252: 4305-4312.

32. Leibovich, S. J. 1978. Production of macrophagedependent fibroblasts stimulating activity (M-FSA) by murine macrophages. Exp. Cell. Res. 113: 47-56.

33. Young, M., J. Oyer, M. H. Blanchard, H. Asdovrian, H. Amos, and B. G. W. Arnason. 1975. Secretion of nerve growth factor by primary chick fibroblast cultures. Science (Wash., D. C.). 187: 361-362.

34. Hakim, A. A. 1978. Isolation of a growth-stimulating agent from human skin fibroblasts cultures. Experimentia (Basel). 34: 1515-1517.

35. Millis, A. J., M. Hoyle, and B. Field. 1978. Human fibroblast conditioned media contains growth promoting activities for low density cells. J. Cell. Physiol. 93: 17-24.

36. Weidman, E. R., P. Atkison, and R. M. Bala. 1979. Production of somatomedin and mitogenic effects of somatomedin on human fibroblasts. Presented at the 61 st
Meeting of the Endocrine Society, Anaheim, California, June 13-15.

37. Salmon, W. D., and W. H. Daughaday. 1957. A hormonally controlled serum factor which stimulates sulfate incorporation by cartilage in vitro. J. Lab. Clịn. Med. 49: 825-836.

38. Zapf, J., M. Waldvogel, and E. R. Froesch. 1975. Binding of non-suppressible insulin-like activity to human serum. Evidence for a carrier protein. Arch. Biochem. Biophys. 168: 638-645.

39. Clemmons, D. R., and J. J. Van Wyk. 1980. Somatomedin$\mathrm{C}$ and platelet derived growth factor stimulate human fibroblast replication. J. Cell. Physiol. In press.

40. Harker, L. A., R. Ross, S. J. Slichter, and C. R. Scott. 1976. Homocysteine-induced arteriosclerosis: the role of endothelial cell injury and platelet response to its genesis. J. Clin. Invest. 58: 731-741.

41. Lesniak, M. A., P. Gorden, and J. Roth. 1977. Reactivity of non-primate growth hormones and prolactin with human growth hormone receptors on cultured human lymphocytes. J. Clin. Endocrinol. Metab. 44: 838-849. 